\title{
The Effect of Acceptability and Enforceability of International Financial Reporting Standard (IFRS) on Global Accounting Standard Convergence
}

\author{
Siti Zabedah Saidin \\ Mu'azu Saidu Badara \\ Mohammed Lawal Danrimi \\ School of Accountancy, Universiti Utara Malaysia \\ muazubadara@yahoo.com
}

Doi:10.5901/mjss.2014.v5n10p295

\begin{abstract}
In spite the important of the global accounting convergence of IFRS in firms operations of various countries in terms of globalization of financial markets, standardizing the diverse accounting policies around the globe and the facilitation of high quality, transparent and comparable information in financial statements. But then, only few developing and even developed nations give concerned on such global accounting convergence of IFRS. In line with this, the objective of this paper is to examine the effect of two variables i.e. IFRS acceptability and IFRS enforceability on such global accounting convergence of IFRS through the perceptions of preparers and users of financial reporting. Data of the study were collected through self administered and online survey, in which 300 questionnaire was sent to the preparers and users of financial reporting in Nigeria. The study used convenient sampling technique; data were analyzed using Statistical Package for Social Science (SPSS) version 19. Descriptive statistic, factor analysis, correlation matrix and finally, multiple regression analysis were carried out. The result findings of the analysis revealed that, IFRS acceptability and IFRS enforceability has significant positive relation with the global accounting convergence of IFRS. Finally, conclusion was provided and the direction for future research was also provided.
\end{abstract}

Keywords: IFRS acceptability, IFRS enforceability, global accounting convergence, companies,

\section{Introduction}

Considering the old maxim that "Accounting is the language of business", then enterprises around the globe cannot afford to be speaking in different languages while communicating the financial information of their activities to one another. Thus, a uniform set of accounting standards is needed to enhance the level of understanding and comparability of the firms' financial reporting across the world (Ojeka \& Dickson, 2011). In this vein, International Financial Reporting Standards (IFRS) are designed as a common global language for the company's activities in order to improve the quality, understanding and comparability of financial reporting across International boundaries. This enable various companies across the world assimilating such IFRS in reporting their financial statement so that to meet up with the world standard in financial reporting.

The above issues lead to the emergence of global accounting standard convergence across the countries. This is in line with the fact, in order to attain greater comparability in financial statement, efficient allocation of resources, reduction in the cost of capital, increase willingness to invest across borders, and higher economic growth, global accounting standard convergence was the they driver to this success (Wong, 2004). Likewise, Chakrabarty (2011) expressed that global accounting convergence enable the assessment of firms operations in diverse environment and thereby enhance the investors confident in such firms.

Despite the above mentioned advantages over the adoptions and convergence with IFRS in financial reporting system of a firm, many companies around the world have already converged with such IFRS for their corporate financial reporting system sustainability, while some countries are still assessing the impact of such convergence before fully adoptions. In spite the pressing demands to converge with IFRS as the international accounting benchmark and to serve as common global accounting language. Nevertheless, many developing countries are still showing low concern over such convergence with IFRS take for instance Nigeria (Okaro \& Tauringana 2012). This was equally due to the fact that, there is doubt on such convergence in terms of its uniform suitability and relevance in diverse economic, political and institutional settings across the globe (Liu, Yao, Hu \& Liu, 2011), that is why only limited listed companies complied with it 
in Nigeria (Okpala, 2012).

Even the developed nations encounter such problem of compliance with IFRS, because the result survey of Association of Chartered Certified Accountants (ACCA) has reaffirmed that, Nigeria is not the only country with sluggish adoption attitude, similar experience is being faced in some other countries. In view of the above issues, the objective of this paper is to examine whether IFRS acceptability and IFRS enforceability may have any influence on such global accounting standard convergence. Section two of the paper presents the literature review and hypothesis development, section three provides research methodology, section four present the results and discussion and finally the conclusion.

\section{Literature Review and Hypothesis Development}

\subsection{Global Accounting Convergence}

The idea of accounting standards convergence can be traced back to the 19th century, when the conception of international standards took essence during the 1st international congress of accountants in 1904 (Ball, 2006). In the 1950s, in response to integration of economies and improvement in cross border trade after the Second World War, the idea of convergence also deepened (Floropoulos, 2006). The call continued until 1966 when prominent professional accountancy bodies of the world namely; the Institute of Chartered Accountants of England and Wales, Association of Certified Public Accountants of America, and Canadian Institute of Chartered Accountants emanated together to deliberate on the need to have International Accounting Standards. The meeting was then chaired by the president of Institute of Chartered Accountant of England and Wales in person of Sir Henry Benson. According to them, after extensive discussion, the bodies decided to form a study group to carry out comparative studies on accounting practices amongst the participating states.

During the eleven year life span of the group, about 20 studies were performed on accounting and auditing issues and subsequently, the group resolved to establish International Accounting Standards (Das, Shil \& Pramanik, 2009). The establishment of International Accounting Standards led to the formation of the International Accounting Standards Committee (IASC) in 1973, this committee was saddled with responsibilities of setting International standards. This was as a result of the consensus by the sixteen professional accounting bodies from; Australia, UK, USA, Canada, Japan, Ireland, France, Germany, Mexico and Netherlands (Floropoulos, 2006). IASC performed very brilliant jobs, because it's among their success, the development of 41 different set of standards to take care of different financial reporting matters. Even though, IASC lacked the power in promoting the standards, ensuring its application and achieving universal harmonization among various countries. But then, they did a wonderful job.

As financial markets are becoming more global, world economies are becoming more interconnected, couple with the fact that no country can brag "self-reliance" without depending on another country (Europeens, 2001) the situation further suggested the need to improve the activities of IASC in order to achieve the objective of global accounting harmonization. In 2001, as part of the effort, IASC was restructured and renamed to International Accounting Standard Board (IASB) to continue with reforms and improvement of the plans so that to expedite the achievement of the Board objectives (Cortese, \& Irvine, 2010). Part of the improvement efforts; International Accounting Standards (IAS) was retitled to IFRS and was made more flexible than IAS (Paglietti, 2009). At the outset, the idea was to harmonize the accounting standards, i.e. to minimize the variances that existed in the accounting principles being applied in the major capital markets across the globe, but the notion of harmonization was later replaced by the concept of convergence, which aims at achieving single uniform set of high quality global standards that can be applied at least in all the major capital markets around the world (Paglietti, 2009).

IFRS are designed as a common global language for the company's activities in order to improve the quality, understanding and comparability of financial reporting across international boundaries. The standards are said to achieve three fold objectives; firstly, assisting in standardizing the diverse accounting policies existing around the world and eliminate the incomparability of financial statements within and across entities. Secondly, facilitate the presentation of high quality, transparent and comparable information in financial statements. Thirdly, reduce to accounting alternatives and thereby eliminate the element of subjectivity in financial statements (Chakrabarty, 2011).

In line with the above, the questions that demand for an answer is whether IFRS is feasible to all countries of different settings, especially the developing nations. This is because, looking at the trend in the International Accounting Standards setting processes, it was clear that the founders of this global standards were all from the highly industrialized economies, sharing common characteristics in most cases and the decision to have these common accounting standards was taken based on the situation that best fit the participating countries, in terms of economy, laws and regulations, politics etc. None of the developing countries was considered in the comparative studies carried out which later led to the 
development of IAS (now IFRS). Therefore, this enables researchers concerned to determine the rationale behind its development. To this end, the researchers come out with the notion that; diversity in culture, politics, law and regulations and business environments among countries is large, that single set of accounting standards cannot be applicable to all countries. While others suggested that the flexibility of global accounting standards should allow the disparity in culture, politics, laws and regulations and business environment to be accommodated under single set of accounting standards.

In this vein, Wong (2004); argues that converging to a single set of accounting standards can be seen as effectively realised when the financial information allows investors to make comparison, when it lowers cost of capital, when the allocation of firms' resources is seen to be efficient and when high economic growth is achieved. Hail, Leuz, and Wysocki (2009) believes that global accounting convergence is likely to improve the quality of firms' reporting system, reduce the firms cost of capital and enhance market liquidity. Because it was found that, convergence to IFRS enable investors to figure out opportunities better, enable multinational corporations to use common accounting language in the preparation and presentation of their financial statements using similar language of that of their competitors (Bartov, Goldberg, \& Kim, 2005).

In the study carried out by Ikpefan, and Akande (2012) expressed that, convergence of global accounting standards cannot be separated from politics, increased compliance cost, and deprivation of business operations. According to the study, accounting standards setting is often being inspired by political motives to transfer resources from less desirable sector to most desirable ones and the effects of this resources transfer is usually being influenced by interest groups by way of lobby. In respect to the cost implications, the study opines that global accounting convergence would create one-off convergence costs and continuous maintenance costs of the global standards as well as costs of training the regulators, preparers, auditors and other financial professionals and the cost of retaining the trainers for a reasonable period of time. Regarding the deprivation of business operation, the study claims that many businesses would be deprived the opportunities to run their businesses in jurisdictions that apply the accounting standards that best suits their line of business.

To this end, it can be understood that, international accounting convergence is crucial and timely in this era of increased globalization. Although, it might create some difficult experience, but then, the benefits to be derived from it seem to overshadow the problems. It is expected to result in consistency and uniformity of the financial system, minimizes cost of doing business and serves as a protective measure to investors by increasing their confidence no matter where the business occurs. It is also believed that investors' willingness to diversify their investments across international boundaries will be encouraged if financial information are prepare under single set of standards that can be relied by them. Despite the above advantages of such convergence, only limited companies converge with the international accounting standard especially the developing nation. Therefore, in view of that, this research demonstrated the effect of IFRS acceptability and enforceability on global accounting standard convergence.

\subsection{IFRS Acceptability}

For financial reporting to be credible, the standards upon which the financial statement is prepared must be acceptable. The financial standard should be design in such a way to be well suitable and applicable (Wulandari \& Rahaman, 2004). In regard to previous study, Zeff (2008) study the determinants of voluntary acceptance and adoption of IFRS by some listed firms on the unregulated market by analysing their annual reports. The study reveals that, certain vital elements are observed to be the determinants of voluntary acceptance and adoption of IFRS in these firms, these include; firm size, firm assets and the industry. They highlight that the larger the size of a firm the greater its possibility to voluntarily accept and adopt IFRS. The study recommend that firms' size, firms' assets is another important element in determining voluntary acceptance and adoption of IFRS, as heavy investments in assets serve as a protector and tend to constitute strong entry barrier to firms wishing to switch to IFRS. Finally, they suggested that, Industry is another determinant of voluntary acceptance and adoption of IFRS; for instance, firms under utility or consumer goods industry may not likely to accept and adopt IFRS than firms under other sectors.

Dholakia (2013) stated that, the shift to IFRS by the some countries credit organization in the recent period is considered as a giant stride towards achieving global accounts harmonization in such countries. Preparers of accounts from various country's especially banking sector expressed their total support towards the application of the common global accounting standards, describing it as a positive development in the country's reporting system and the assessment of cost-benefit is perceived to be positive. This contradicts the finding of the survey conducted by Jermakowicz \& Gornik-Tomaszewski (2006) who attempts to determine the level of acceptability of IFRS and its application by investment funds supervisors as well as determining how well-informed and appreciative investment funds administrators and managers were, with regards to IFRS, in 41 European Union Countries. 
The survey shows low level of acceptability among the fund supervisors in which $79 \%$ of them expressed their preferences of local GAAP to IFRS in achieving quality reporting system in the industry. In addition, majority of the fund managers (58\%) also preferred using the domestic GAAP to IFRS while $22 \%$ of the managers that have already incorporated both IFRS and local GAAP in their reporting system express no intention of total switch to IFRS. The common idea in the responses generated, indicates that IFRS would only be applicable when it is made mandatory (Jermakowicz \& Gornik-Tomaszewski, 2006). Therefore, this indicates that the acceptability of IFRS required some enforcement from the authority concerned.

Pawsey (2010) conducted a survey in Australia in 2005 and 2008, to determine the perceived quality and complexity of the global standards, the result reveals different degrees of acceptability amongst the account preparers towards the quality of IFRS. According to study, the 2005 survey reveals; majority of account preparers surveyed disagree with the perceived quality attributed to IFRS as in their opinions is more complex than Australian standards. To them IFRS lacks the quality of being accepted. But as time passes by, the perceptions of the preparers seemed to change; the result of 2008 survey indicates improved acceptance of IFRS as a quality standards in terms of stringent application guidance on certain issues not addressed by Australian standards, but they believed that IFRS compared to Australian standards is more complicated, costly, time consuming, and leads to user confusion.

Jones and Higgins (2006) conducted a surveyed among 60 Australian firms, believed to be among the top 200 companies in the country, to determine how account preparers in these firms accept the shift from Australian Accounting Standards to IFRS. The result signposts that numerous of the respondents expressed cynicism in the presumed benefits to be derived from the single set of global standards, while others were strongly doubtful of the whole Australian reform agenda in respect to the IFRS application, most of the criticism was noticed to largely come from small sized firms in the country, which according to the study raised another concern on whether IFRS would be acceptable and relevant to small sized companies.

Liu et al (2011) stated that, the result of the survey carried out among 163 chief financial officers and investors across Europe, US, Middle East and Asia, reveals less resistance of IFRS by investors and CFOs. The increasing understanding of the standards among investors and CFOs was believed to broke down the resistance attitude with about $40 \%$ of the respondents confessed that IFRS has increased more access to capital, while about a quarter of the respondents believed that IFRS has brought reduction in cost of capital. Many respondents believed IFRS would facilitate consistent regulation, bring greater disclosure in presentation of information regarding financial reporting and sustainability and corporate governance report would also be more transparent.

Equally, the study of James, (2009) displayed that IFRS knowledge and acceptance by accounting students are considered as important contributing factors towards the successful IFRS journey. The study attempts to explore how accounting students and other related discipline perceive and accept IFRS as a quality accounting system of reporting, using a structured questionnaire to generate relevant data on the subject. The study reveals that, the acquisition of IFRS knowledge is more important than the acquisition of the existing accounting knowledge by the students of accounting in this contemporary accounting world. Hence, $75 \%$ of the respondents expressed acceptance and confidence in IFRS as global quality reporting standards capable of improving accounting reporting system. Although, students from other related disciplines seemed to accept US GAAP as more appropriate global accounting standards than IFRS, while accepting the US GAAP as another quality standards. The study concluded that students of accounting reasoned that the internationalization and the interconnectivity of financial markets demonstrate the relevance of IFRS knowledge in updating the existing accounting knowledge and in providing accounting graduates with greater opportunities in the world financial markets.

Zeff (2008) reveals firm size, firm assets and the industry to be vital elements determinants of voluntary acceptance and adoption of IFRS. Dholakia (2013) reveals that, preparers of accounts from the banking sector expressed their total support towards the application of the common global accounting standards, describing it as a positive development in the country's reporting system and the assessment of cost-benefit is perceived to be positive. The finding of Jermakowicz, and Gornik-Tomaszewski (2006) shows low level of acceptability among the fund supervisors with 79\% of them showed their preferences of local GAAP to IFRS in achieving quality reporting system in the industry. While Liu et al, (2011) stated that the result of the survey carried out among 163 chief financial officers and investors across Europe, US, Middle East and Asia, reveals less resistance of IFRS by investors and CFOs. In addition, James (2009) explores how accounting students and other related discipline perceive and accept IFRS as a quality accounting system of reporting. Most of the respondents expressed acceptance and confidence in IFRS as global quality reporting standards capable of improving accounting reporting system. In view of the above, the first hypothesis is:

$\mathrm{H} 1$ : There is a positive significant relationship between IFRS acceptability and the convergence to IFRS. 


\subsection{IFRS Enforceability}

The introduction of IFRS in any particular jurisdiction would simply constitute a part in the laws and regulations existing in that jurisdiction relating to how business affairs are being governed. Often times, these laws and regulations try to overlay one another or simply become inconsistent especially when sound enforcement mechanisms are absent or the role of various institutions responsible for the enforcement are not well defined (NASB, 2010). The role of institutional infrastructures in ensuring rigorous and effective application of IFRS cannot be over emphasized. Realizing the benefits attached to these global standards requires strong legal, institutional and professional support (Europeens, 2001). Hence, lack of stringent and clearly define enforcement and regulatory system as well as quality professional accountants may result in inefficiency and inappropriate application of IFRS. Moreover, for the adoption of IFRS to be effective, there should be an adequate awareness campaign and improvement in the quality of a professional accountant, at the same time, professional accountants are required to give orientation on how IFRS are being applied (James, 2009).

Wulandari and Rahaman (2004) assert that having accounting standards in place, does not guarantee effective regulation mechanism; institutional infrastructures for the application and enforcement of these standards are also vital in providing the standards with the aptitude to make financial information relevant for all capital markets. Strong institutional infrastructures and sound enforcement apparatus will enable investors to develop confidence that financial reports reveal a true and fair view of the firm's fundamentals. In addition, enforcement mechanisms are indispensable elements in the application of IFRS, unless consistently and rigorously enforced, so that perceived benefits of the new set of standards can be reaped (NASB, 2010).

Paglietti (2009) reveals that countries with sound enforcement changes during IFRS introduction, tended to benefit more from increased liquidity than countries with no changes in enforcement mechanisms. The study confirms that countries that made changes in the enforcement mechanism without even moving to IFRS also experienced increased liquidity benefits than countries that did not make changes in the enforcement mechanism during the IFRS adoption. Therefore, changes in enforcement mechanism play a vital role in attaining liquidity benefits before and after IFRS introduction. Hence, achievement of IFRS targeted objectives can be concurrently accomplished with proper and sound enforcement mechanism in place.

Pawsey, (2008) explore how effective is enforcement mechanism in realising the benefit of IFRS, using firm-month observations of 391,462 firms from 51 countries in Europe and Australia that mandatorily apply IFRS, with US and Canadian firms used as control sample between recent financial year. The study reveals lesser error and low dispersion for users of IFRS as well as firms in jurisdictions with strong enforcement mechanism. In this vein, robust institutional infrastructures and strong monitoring mechanism were found to be an important factor in improving reporting quality and reducing income smoothing for both domestic and cross border listed firms in the UK after the adoption of IFRS, (Jermakowicz, \& Gornik-Tomaszewski, 2006).

Having Accounting Standards in place do not guarantee effective regulation mechanism; institutional infrastructures for enforcement and monitoring the application of these standards are also vital in providing the standards with the ability to make financial information relevant for all capital markets (Wulandari \& Rahaman, 2004). Paglietti (2009) equally reveals that, countries with sound enforcement changes concurrent with IFRS introduction seemed to benefit more from increased liquidity than countries with no changes in enforcement mechanisms. Therefore, the second hypothesis is;

$\mathrm{H} 2$ : There is a positive significant relationship between IFRS enforcement and the convergence to IFRS

\section{Research Methodology}

The data for this study was generated from the questionnaires administered to users of financial report such as (investment analysts and auditors) and preparers of financial report such as (financial officers) in Nigeria. The population of the study constitute the entire 183 preparers of the Nigerian listed companies and 225 users of Investment analyst firms as sourced in Okpala (2012), thereby making the total population of 408. By virtue of this population, the sample size required for the study is 201 (Watson, 2001), to reduce the sample error in order to take care with non-response problem, the sample size has been increase to 300 (Hair, Black, Babin \& Anderson, 2010). The sampling technique employed is convenience sampling technique which involves selecting the respondents who are conveniently available to provide the needed response to the researcher. Such technique is often considered as the best means of generating information as quickly and efficiently as possible (Sekaran \& Bougie, 2009), in order to quick retrieval of the complete questionnaire and to obtain a high response rate. The data were obtained through self-administered method as well as online survey, in which out of 300 questionnaires were administered. 205 were fully completed and returned which represent $68 \%$ responds rate. A response rate of $30 \%$ is acceptable for survey (Hair et al, 2010). 


\subsection{Measurement of research variables}

The dependent variable (global accounting convergence) is measured with 10 items as adapted with some modification to suit the context of the study (Rezaee, Smith and Szendi 2010), likewise the two independent variables; IFRS acceptability and IFRS enforceability were all measured with 10 items as adapted with some modification to suit the context of the study (Rezaee et al, 2010). Hence, five -point type rating scale, ranging from strongly agree to strongly disagree has been used in measuring the responses of the entire questions. This is because; the scaling system was used by lyoha and Jimoh (2011), and found suitable.

Face and content validity of the instrument was carried out through meeting with the expert on the field in order to ensure that those items that contain in the instrument actually belong to that particular instrument. The expert contacted consisted of Directors / Finance Managers of Nigerian Listed companies. They were considered to be responsible for the preparation of financial statements of the respective organizations. While the users of financial reports contacted are Investment analyst of firms identified from the list of Capital market operators compiled by the Nigerian Stock Exchange. To this end, after taking note on the expert observation, a revised version of the instrument was then developed, which resulted to some questions were change so that to measure the constructs appropriately, so that to enable clear understanding by the potential respondents, which thereafter administered for pilot study. The reliability of the pilot study was all above 0.7 which indicate the reliability of the measurement (Hair, et. al, 2010).

\subsection{Method of data analysis}

The data were analyzed using SPSS version 19.0, hence descriptive statistic was conducted, factor analysis was equally carried out so that to reduce the items into more manageable number (Pallant, 2001) in which after the factor analysis, the items remain for each variable certified the requirement of factor analysis, such as KMO $>0.5$, Bartlett's test of Sphericity $p<0.05$ or smaller, communalities $>0.5$, factor loading above $>0.5$ (Hair et al, 2010), as you can see the factor loadings and the cronbach alpha of the variables in table 2, correlation matrix has been carried out and lastly, multiple regression analysis was then conducted.

\section{Result and Discussions}

\subsection{Descriptive statistic}

Table 1.0 below present the demographic characteristic of the respondents in terms of their gender, ages, educational qualifications and their organisational categories, the result reveals that $78 \%$ of the respondents are male while $22 \%$ of the respondents are female; this implies that the number of male outweighs the number of female respondents. Descriptive statistic result indicates that $48.8 \%$ of the respondents are within the age of $30-40$ years old which implies that the majority of respondents are within the reasonable productive age group of the entire population. With regard to educational qualification, the result shows that majority of the respondents are within educational level of M.Sc., MA, or MBA with 59\% which is quite impressing. And lastly, the organizational categories of the result reveals that must of the respondents are preparers which are from listed companies with $59 \%$.

Table 1: Summary of the demographic characteristic of the respondents

\begin{tabular}{llcc}
\hline Demographic profile & Categories & Frequency & $\%$ \\
\hline \multirow{2}{*}{ Gender: } & Male & 160 & 78.0 \\
& Female & 45 & 22.0 \\
& Total & 205 & 100.0 \\
\hline \multirow{3}{*}{ Age: } & $20-30$ & 25 & 12.2 \\
& $31-40$ & 100 & 48.8 \\
& $41-50$ & 50 & 24.4 \\
& $51-60$ & 30 & 14.6 \\
& Total & 205 & 100.0 \\
\hline \multirow{3}{*}{ Educational qualification } & B.Sc./HND & 70 & 34.0 \\
& M.Sc./MA/MBA & 120 & 59.0 \\
& PhD/DBA & 15 & 7.0 \\
& Total & 205 & 100.0 \\
\hline \multirow{2}{*}{ Organizational category } & Listed company & 120 & 59.0 \\
& Investment Analyst & 85 & 41.0 \\
& Total & 205 & 100.0 \\
\hline
\end{tabular}


Table 2: Results of Measure Validation

\begin{tabular}{lcc}
\hline Items & Factor Loadings & Cronbach Alpha \\
\hline Global Accounting Standard Convergence (GAC) & $0.62-0.81$ & 0.73 \\
IFRS Acceptability (IFRSA) & $0.69-0.78$ & 0.85 \\
IFRS Enforceability (IFRSE) & $0.67-0.80$ & 0.84 \\
\hline
\end{tabular}

Table 2 above, provided the results for both factor loadings and Cronbach alpha, it can be seen from the table that the factor loading of the variables range from $0.62-0.81$, hence, it is an indication of construct validity (Hair et al, 2010). The cronbach alpha value indicates the constructs reliability because the value range from $0.73-0.85$, hence, is indicating that scales of all measures appear to produce internally consistent results (Hair et al, 2010).

Table 3: Correlation Matrix

\begin{tabular}{lccc}
\hline & GAC & IFRSA & IFRSE \\
\hline Global Accounting Standard Convergence (GAC) & 1 & & \\
IFRS Acceptability (IFRSA) & $.687^{\star *}$ & 1 & \\
IFRS Enforceability (IFRSE) & $.787^{\star *}$ & $.632^{\star *}$ & 1 \\
*. Correlation is significant at the 0.01 level (2-tailed). & & & \\
$*$ Correlation is significant at the 0.05 level (2-tailed). & &
\end{tabular}

The correlation analysis of the research variables was subjected to a two- tailed test of statistical significance at two different level; significant $(p<0.01)$ and significant $(p<0.05)$, table 3 above shows that correlations between the research variables are statistically significant at $(p<0.01)$ respectively. It can also be seen from the same table that the correlation of the variables ranges from 0.632 to 0.787 . Hence, the problem of multicollinearity is not there.

Table 4: Multiple Regression between IFRS Acceptability, IFRS Enforceability on IFRS Convergence

\begin{tabular}{cccccc}
\hline & \multicolumn{2}{c}{ Unstandardized Coefficients } & Standardized Coefficients & & Sig. \\
\cline { 2 - 4 } (Constant) & $\mathbf{B}$ & Std. Error & Beta & & t \\
acceptability & 1.741 & 0.243 & & 7.149 & 0.000 \\
enforceability & 0.221 & 0.090 & 0.271 & 2.451 & 0.016 \\
\hline
\end{tabular}

Table 4 above displayed the result of regression analysis of the relationship between IFRS acceptability and IFRS enforceability on IFRS convergence. IFRS acceptability has significant positive relationship with global accounting convergence $(\beta=.271, t=2.451, p=.016)$. This finding implies that global accounting convergence of companies depend upon the acceptability of such IFRS. The finding is in line with the previous studies (Razaee et al, 2010; Liu, 2011; James, 2009). Thus, hypothesis 1 which stated that there is positive significant relationship between IFRS acceptability and global accounting convergence is fully support. Therefore, for nations companies to succeed in global accounting convergence, IFRS acceptability is one of the determinant factors.

Also, the table 4 above reveals the significant effect of IFRS enforceability on the global accounting convergence $(\beta=0.423, t=3.826, p=.000)$. This implies that IFRS enforceability plays very significant roles in the global accounting convergence. This finding is in line with the previous studies (Wulandari \& Rahaman, 2004; NASB, 2010). Hence, hypothesis 2 which stated that there is positive significant relationship between IFRS enforceability and global accounting convergence is fully support. Therefore, for nations companies to succeed in global accounting convergence, IFRS enforceability is other determinant factors to be consider.

\section{Conclusion}

This study provided the empirical evidence on the relationship between IFRS acceptability and IFRS enforceability on the global accounting convergence of IFRS through the perceptions of preparers and users in one of the developing nation which is Nigeria. The result analysis of the study reveals the significant effect of IFRS acceptability and IFRS enforceability on the global accounting convergence of IFRS relationship, which implies that, the ability of nation's realization of global accounting convergence of IFRS in their firms operations depend upon their level of IFRS acceptability and IFRS enforceability. Some of the limitation of the study includes; collecting data from preparers and users only from Nigerian operations despite other nation's operation, the research was based on cross-sectional and the 
finding cannot be generalized due to different setting of various companies operations in different countries.

Despite the above limitations, the study contributed to the global accounting convergence of IFRS by providing empirical evidence of IFRS acceptability and IFRS enforceability over such convergence. Therefore, more research are require to be conducted on global accounting convergence of IFRS, in fact future studies should incorporate other necessary factors that may aid such global accounting convergence of IFRS in the world. Future studies should equally conduct a qualitative research on why some companies in the developing nations even the developed one are showing unserious concern over the global accounting convergence of IFRS.

\section{References}

Ball, R. (2006). International Financial Reporting Standards (IFRS): Pros and cons for investors. Accounting and business research, 36(sup1), 5-27.

Bartov, E., Goldberg, S. R., \& Kim, M. (2005). Comparative value relevance among German, US, and InternationalAccounting Standards: A German stock market perspective. Journal of Accounting, Auditing \& Finance, 20(2), 95-119.

Chakrabarty, K. (2011). KC Chakrabarty: Introduction of International Financial Reporting Standards (IFRS)-Issues and challenges.

Cortese, C., \& Irvine, H. (2010).Investigating InternationalAccounting Standard setting: The black box of IFRS 6.Research in Accounting Regulation, 22(2), 87-95.

Das, B., Shil, N. C., \& Pramanik, A. K. (2009). Convergence of Accounting Standards: Internationalization of Accounting. International Journal of Business and Management, 4(1), 78 - 90.

Dholakia, P. (2013). A Perceptual Study of the Implementation of International Financial Reporting Standards for Enhancing Accounting Financial Transparency. The IUP Journal of Accounting Research \& Audit Practices, 12(1), 63-79.

Europeens, F. d. E. C. (2001). Enforcement mechanisms in Europe: a preliminary investigation of oversight systems. IAS PLUS: http://www. iasplus. com/restruct/euro2001. htm.

Floropoulos, I. (2006). IFRS. First time users: Some empirical evidence from Greek companies. Spoudai: Journal of Economics and Business, 56(3), 39-70.

Hail, L., Leuz, C., \&Wysocki, P. (2009). Global Accounting convergence and the potential adoption of IFRS by the United States: An analysis of economic and policy factors. Available at SSRN 1357331

Hair, J., Black, W. C., Babin, B. J, \& Anderson, R. E. (2010). Multivariate danalysis (7th Edition). Uppersaddle River, New Jersey: Pearson Education International.

Ikpefan, O. A., \& Akande, A. (2012). International Financial Reporting Standard (IFRS): Benefits, Obstacles And Intrigues For Implementation In Nigeria. Research Journal of Finance and Accounting, 3(10), 143-151.

Iyoha, F., \& Jimoh, J. (2011). Institutional Infrastructure and the Adoption of International Financial Reporting Standards (IFRS) in Nigeria. School of Doctoral Studies European Union, 17.

James, M. L. (2009). Accounting for global entities and the effect of the convergence of US generally accepted Accounting principles to International Financial Reporting Standards. Journal of the International Academy for Case Studies, 15(5).

Jermakowicz, E. K., \& Gornik-Tomaszewski, S. (2006). Implementing IFRS from the perspective of EU publicly traded companies. Journal of InternationalAccounting, Auditing and Taxation, 15(2), 170-196.

Jones, S., \& Higgins, A. D. (2006). Australia's switch to International Financial Reporting Standards: a perspective from account preparers. Accounting \& Finance, 46(4), 629-652.

Liu, C., Yao, L. J., Hu, N., \& Liu, L. (2011). The Impact of IFRS on Accounting Quality in a Regulated Market An Empirical Study of China. Journal of Accounting, Auditing \& Finance, 26(4), 659-676.

Nigerian Accounting Standard Board (NASB) (2010).Report of the Committee on Road Map to the Adoption of International Financial Reporting Standards in Nigeria.

Ojeka, S. A., \& Dickson, D. O. M. (2011).International Financial Reporting Standard (IFRS) and SMEs in Nigeria: Perceptions of Academic. International Journal of Research in Commerce and Management.

Okaro, S. C., \& Tauringana, V. (2012). From SAS to IFRS: An Investigation of Nigeria Transition Road Map Implementation Problems. Research in Accounting in Emerging Economies, 12, 155-176.

Okpala, K. E. (2012). Adoption of IFRS and Financial Statements Effects: The Perceived Implications on FDI and Nigeria Economy. Australian Journal of Business and Management Research Vol, 2(05), 76-83.

Pallant, J. (2001). SPSS survival manual. A step by step guide to data analysis using SPSS for windows (Version 10) (1 ${ }^{\text {st }}$ Edition). Allen \& Unwin Australia.

Paglietti, P. (2009). Investigating the Effects of the EU Mandatory Adoption of IFRS on Accounting Quality: Evidence from Italy..International Journal of Business and Management, 4(12), P3.

Pawsey, N. L. (2008). Australian Preparer Perceptions Towards The Quality And Complexity Of IFRS. La Trobe University.

Rezaee, Z., Smith, L. M., \& Szendi, J. Z. (2010). Convergence in Accounting Standards: Insights from academicians and practitioners. Advances in Accounting, 26(1), 142-154.

Sekaran, U, \& Bougie, R (2009). Research method for business; A skill building approach. Fifth edition. A john Wiley and sons, Ltd. United Kingdom.

Watson, J. (2001). How to Determine a Sample Size: Tipsheet 60, University Park, PA: Penn State Cooperative Extension. Retrieved on 21/10/2012 from http://www.extension.psu.edu/evaluation/pdf/TS60.pdf

Wong, P. (2004). Challenges and successes in implementing International standards: achieving convergence to IFRSs and ISAs.

Wulandari, R. E., \& Rahaman R. A (2004). A cross-country study on the quality, acceptability, and enforceability of Accounting Standards and the value relevance of Accounting earnings.

Zeff, S. A. (2008). IFRS Developments in the USA and EU, and Some Implications for Australia. Australian Accounting Review, 18(4), 275-282 